\title{
$\underline{\text { Literary Critics at Work and Their Information Needs: A Research-Phases Model* }}$
}

By: Clara M. Chu

Chu, Clara. "Literary Critics at Work and their Information Needs: A Research-Phases Model," Library and Information Science Research, 21(2): 247-73, 1999. doi:10.1016/S0740-8188(99)00002-X

Made available courtesy of Elsevier: http://www.elsevier.com/wps/find/journaldescription.cws_home/620211/description

\section{***Note: Figures may be missing from this format of the document}

\begin{abstract}
:
This article focuses on the information needs of literary critics when producing literary criticism. A fundamental aspect of this research, the six-stage model of producing literary criticism, was developed from interviews with literary critics. Using a mail survey, the model was tested and substantiated. The research-phases model provides the context to understand the function of information at each of the identified stages of literary criticism, that is, idea generation, preparation, elaboration, analysis and writing, dissemination, and further writing and dissemination. The model is contrasted with research-phases models of other disciplines. This holistic approach, linking information functions to research stages, advances the study of information-seeking behavior in context.
\end{abstract}

\section{Article:}

Librarians have long considered the library as the humanist's laboratory and its books as the humanist's instruments. Such a perception has been corroborated by studies of library and collection usage which convey the extent of library and material use and the characteristics of the material used. Less is known about humanists' information-seeking behavior that does not emphasize library use. Traditional information needs and uses studies represent an atomistic approach which focuses on "user behavior primarily in the context of user intersection with systems" (Dervin \& Nilan, 1986, p. 14). For information professionals to be effective information providers, they require a fuller understanding of humanists' information needs and uses, such as their information needs beyond the characteristics of needed materials, the context of the research process in which information needs occur, how information is used, and whether their information needs have been met. This holistic approach to studying information needs and uses in the context of research activities not only enhances an understanding of information-seeking behavior but it also represents a critical shift in research methodology, because it examines the information that humanists use to advance their work or knowledge. In addition, by providing a comprehensive description of literary critics' information use in the context of their research activities, the framework used in this study responds to Dervin and Nilan's (1986) call for a paradigm shift in needs and uses studies from an atomistic to a holistic approach.

To date, no descriptive model of the research process of literary critics has been developed. This study uses research phases to construct a model that identifies the stages involved in producing literary criticism and the role that information plays at each stage. Research phases/stages ${ }^{1}$ in this study are defined as separate tasks and time spans within the process of literary criticism. Each task may incorporate one or more activities. This article describes the research phases and information use in literary criticism and the working environment of literary critics. It also contrasts this research phases model of literary criticism with research phases models of other disciplines.

\footnotetext{
* An abbreviated version of this article was presented at the 56th Annual Meeting of the American Society for Information Science, 22nd-28th October 1993, under the title "The Information Needs of the Literary Critic: A Descriptive Model." The author would like to thank Joo Y. Cho and Kim M. Woo for their assistance with manuscript preparation.

${ }^{1}$ The terms "phase" and "stage" are used interchangeably.
} 


\section{LITERARY CRITICISM}

This information-seeking study focuses on scholars conducting literary criticism because there is a need to understand the information needs and uses in the distinct disciplines within the humanities. Research on information needs and uses in the humanities has been conducted based on the assumption that all disciplines within the humanities are the same and that all findings may be generalized across these disciplines. ${ }^{2}$ However, no empirical data support this assumption. Needed are studies that address each specific humanities discipline to identify the differences, if any, that may exist and to isolate the special needs of scholars within each discipline. The British Library report, Information Problems in the Humanities (1975), referred to differences in humanistic disciplines and the need to study them separately. More recently, Lönnqvist's (1990) study of the information-seeking behavior and needs of humanities scholars indicated that "scholars in the humanities do not have a homogeneous information seeking behavior or homogeneous information needs. Variations from discipline to discipline can be seen; especially scholars doing research in linguistics or languages behaved differently in the humanities" (p. 29).

The present investigation focuses on the information-seeking behavior of scholars in one humanistic discipline, literary criticism. Literary criticism is a form of literary scholarship, which also includes linguistics, textual scholarship, literary theory, literary history, literary bibliography, literary biography, and cultural studies, among others. Literary criticism "is the analysis and interpretation of texts"3 (Lipking, 1981, p. 83). In an examination of "The Transformation of English Studies: 1930-1995," Abrams (1997) finds texts to be broadly defined: "In the present state of English studies in the American university . . . all intellectual products are reduced to a common condition as texts to be interpreted ... [and] are viewed as the natural province of the putative experts in texts and interpretation who inhabit departments of literature" (pp. 123-124). For this study, texts or works of literature are defined as any form of discourse that literary critics choose to consider as literature and to include in literature courses, and about which they write criticism.

\section{LITERARY SCHOLARS: INFORMATION NEEDS AND USES STUDIES}

The body of literature dealing with the information needs and uses of literary scholars is small, and no studies have dealt exclusively with literary critics. Nine works examined the bibliographic characteristics of cited references in literary studies. The various foci included American literature (Budd, 1986a; Gleaves, 1961), English literature (Heinzkill, 1980), monographic scholarship of foreign literary studies by native speakers of English (Cullars, 1988), literature of two or more national origins (Budd, 1990; Cullars, 1985,1989; Stern, 1983), and citing of native and foreign language materials (Batts, 1972). These citation studies suggest that books are cited more often than other types of materials, such as serial literature, newspapers, manuscripts, and dissertations, and that these scholars tend to cite a greater variety of serial titles and older books than do scholars in other disciplines. These findings provide only a partial picture of the manner in which literary scholars use information and give no indication about how cited material is identified and located.

Two studies analyzed the functions of cited references in an attempt to determine whether humanistic research processes influence citation practices (Frost, 1979; Jaaskalainen, 1985). These analyses reveal the citation process and not the characteristics of the cited works. Two studies examined the literature used by literary scholars and considered the implications for collection management. One is a treatise (Beugnot, 1981) on the topic, and the other is a citation study (Budd, 1986b). The remaining works include a dissertation on the information-seeking behavior of literary scholars in Canadian universities (Hopkins, 1988), a study of the library and information resources and services for users in language and literature (Beh, 1983), an analysis of the readership patterns of five literary journals among literary scholars (Doland, 1984), and a report on what constitutes the literary canon, how it is formed, and how it affects curriculum and, in turn, collection development (Heinzkill, 1980).

\footnotetext{
${ }^{2}$ See Watson-Boone (1994) for a review of the 1983-1992 literature on the information needs and habits of humanities scholars.

${ }^{3}$ The operational definition used in the study was "Literary criticism is the analysis, study, evaluation and interpretation of works of literature" (Chu, 1992, p. 35).
} 


\section{A HOLISTIC FRAMEWORK OF THE RESEARCH PROCESS: RESEARCH PHASES}

Few of the use and user studies conducted to date, whether in the sciences, social sciences, or humanities, have tried to contextualize the information-seeking behavior of the user; that is, they do not describe when information seeking occurs, the frequency with which the behaviors occur, or whether such behaviors are related to specific types of scholarly activities. This neglect of context is particularly evident in studies of information-seeking in the humanities. However, there is a small group of studies (see, e.g., Garvey, Tomita, \& Woolf, 1979; Line, 1974; Menzel, 1966; Stone, 1980; Uva, 1977) that "seek to ascertain what information sources were used at a given phase of research, and then infer the function served by a source from the phase at which it was used predominantly" (Menzel, 1967, pp. 287-288). The theory behind these studies of research phases is that information-seeking activities of researchers take place within the context of the research process and are linked with the various stages or phases of that process (White, 1975).

At the time of the study there was little written on the research phase itself. White (1975) stated that a research phase is usually "considered as a means of delineating separate tasks and time spans within the research process" (p. 338). More recently, Barry (1997) has developed the Research Activity Timeline (RAT), a qualitative data collection and analysis technique that

was developed to investigate traditional and electronic information-seeking activity. The guiding principles behind the technique are to: contextualize information activity and the use of information technology by producing real-life examples set within the context of everyday work; facilitate detailed recall of implicit and forgotten information activities; and investigate change in individuals' information behavior. (p. 153)

The RAT technique evolved from the critical incident technique and the sense- making timeline interview; these methods are comparable to the ones used in this study.

\section{METHODOLOGY}

In order to learn and understand the diverse nature of literary critics' work, data were collected in two stages: the development of a descriptive model of the literary critical process, followed by its testing. The first phase involved structured personal account interviews with literary critics to obtain data for an in- depth analysis of their scholarly activities. The interview approach was modeled after two methods: a methodology for accounts (Brown \& Sime, 1981) and the "time line interview" (Dervin \& Clark, 1987). Brown and Sime (1981) defined an account as "the personal record of an event by the individual experiencing it, told from his point of view. The account interview is the context in which the story is related. Essentially, it provides a social situation for the recounting of the experience with the interviewer's role being that of facilitator" (p. 160). The rationale for using the account is that people can and do recount their experiences, and that the accounts are acceptable as scientific data. The time-line interview is a method of asking people to reconstruct each step taken in a specific situation, wherein a participant tries to explain the nature of a situation, the information gaps experienced, and the kinds of help sought at each step to cope with or to resolve these gaps. This interview method is central to Dervin's sense-making approach to the assessment of information needs (Der- vin \& Clark, 1987).

Each interview addressed three areas: activities particular to the production of one work of literary criticism, general scholarly/research activities, and background information. Each interview was tape-recorded and lasted approximately one hour. During the interview each activity, information needed, and difficulties experienced by the interviewee were written down on index cards and presented to the interviewee chronologically. After the process of producing one recent work of literary criticism was described, each interviewee was asked to review the cards and confirm the sequence and completeness of the 


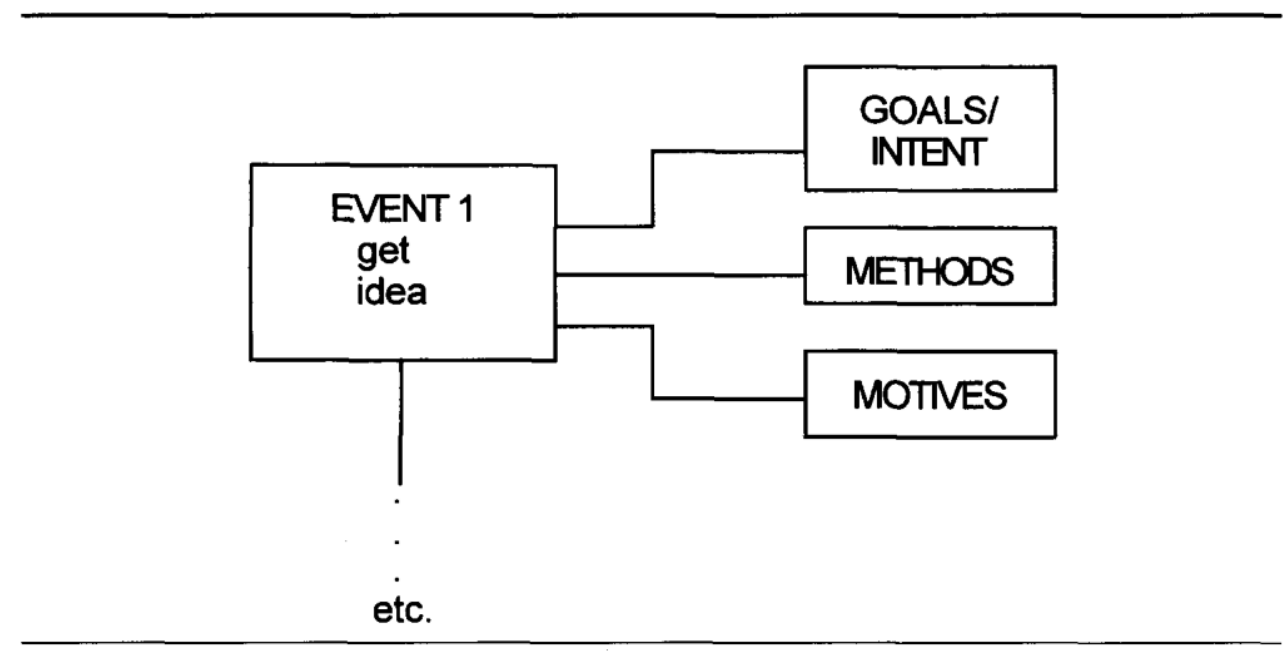

FIGURE 2

Representation of the Associative Process between Information Activities, Usage, and Resources

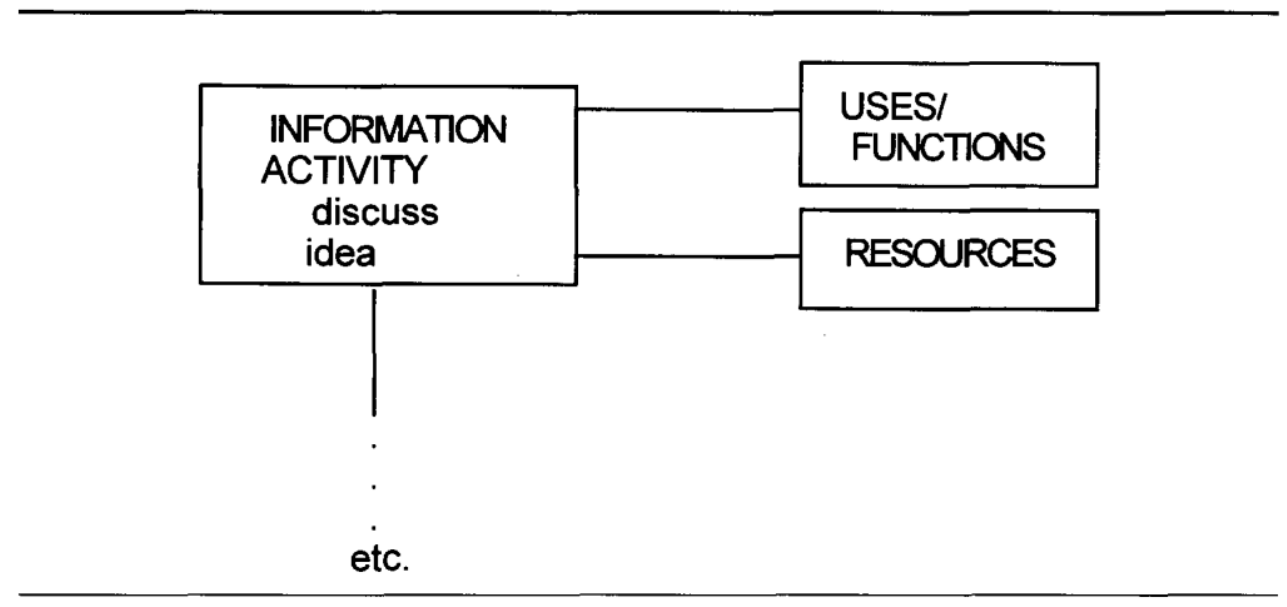

process as represented in the cards. Any activity or other information that was missing would be added at this point.

A random sample of 31 literary critics were interviewed from a pool of 211 potential literary critics at three universities in southwestern Ontario, Canada. Each tape was transcribed and the text/content of both the transcripts and the index cards was analyzed to identify scholarly activities/events and their related cognitive processes (see Figure 1), and information activities and their related usage and resources (see Figure 2).

The work/process of literary criticism described in each interview was considered a case. The events for each case were examined to understand the progression of events. The activities were ordered on a case-by-case basis into natural phases or progression. Each phase included activities sharing a similar purpose which was distinct from another phase. For example, 
Origin of study: events $1-n$

\section{Dissemination: events $\mathrm{n}-\mathrm{Z}$}

The sequences in different cases were then compared to determine if there were enough similarities to suggest a general pattern of behavior. In addition, the cases involving shorter works, such as articles or book chapters, were compared to those involving longer works, such as books. These data generated the preliminary descriptive model of the work of literary critics and the functions served by information.

The second phase of the study, testing of the preliminary model, involved a survey of a large sample of literary critics. The questionnaire focused on four areas: participant's area of literary study, stages of work and information use, other work activities and information sources, and background data. A total of 1,300 potential literary critics at Ontario universities were identified using each institution's 1988-1990 calendar/catalog. Questionnaires were mailed out to a random, systematic sample of 800 literary critics. A total of 281 questionnaires were returned, of which 171 were usable. Unusable questionnaires included 69 responses from literary scholars who did not consider their primary area of work to be literary criticism, 32 non-responses, and 9 refusals to participate. Non-responses were those questionnaires which were returned because the addressee was no longer at the designated university (22), was deceased (2), retired (2), or on sabbatical (6). Refusals included six literary critics who did not have the time to participate and three who did not wish to participate. The response rate, $24.5 \%$ (171 of 699 literary critics), was calculated by excluding the 32 non-responses and the 69 responses from literary scholars who did not consider themselves literary critics.

The survey data were handled in the following manner: (1) all activities in the model were retained unless more than 50 percent of the respondents had indicated that all the associated cognitive processes of an activity occurred "rarely" or was not applicable, "N/A;" and (2) open-ended responses were coded using categories developed from the data.

\section{BACKGROUND AND RESEARCH INTERESTS OF THE LITERARY CRITICS}

This article reports the results related to the development of the research-phases model of literary criticism. A profile of the questionnaire respondents provides the background and range of experiences on which the model is generated. The back-

I ABLE 1

Gender and Rank of Literary Critics

\begin{tabular}{lcccccc}
\hline & \multicolumn{5}{c}{ Academic rank } \\
\cline { 2 - 6 } Gender & Full & Associate & Assistant & Emeritus & Other & Total \\
\cline { 2 - 6 } Female & 6 & 27 & 8 & 0 & 2 & 43 \\
Male & 69 & 39 & 12 & 3 & 1 & $(25.7 \%)$ \\
Total & 75 & $66^{*}$ & 20 & 3 & 3 & 124 \\
& $(44.9 \%)$ & $(39.5 \%)$ & $(12.0 \%)$ & $(1.8 \%)$ & $(1.8 \%)$ & $(100 \%)$ \\
\hline
\end{tabular}

Note: *One associate professor did not indicate his or her gender and is not incorporated into this table. 
TABLE 2

Degrees Held by Literary Critics and Where They Were Obtained

\begin{tabular}{lccccc}
\hline & \multicolumn{3}{c}{ Location } & & \\
\cline { 2 - 4 } Degree & North America & Europe & Other & No Degree & No Response \\
\hline Bachelor & 102 & 35 & 8 & 2 & 24 \\
& $(59.6 \%)$ & $(20.5 \%)$ & $(4.7 \%)$ & $(1.2 \%)$ & $(14.0 \%)$ \\
Master's & 107 & 23 & 7 & 12 & 22 \\
& $(62.6 \%)$ & $(13.5 \%)$ & $(4.1 \%)$ & $(7.0 \%)$ & $(12.9 \%)$ \\
PhD & 105 & 34 & 3 & 15 & 14 \\
& $(61.4 \%)$ & $(19.9 \%)$ & $(1.8 \%)$ & $(8.8 \%)$ & $(8.2 \%)$ \\
Other & 11 & 14 & 0 & 136 & 10 \\
& $(6.4 \%)$ & $(8.2 \%)$ & $(0.0 \%)$ & $(79.5 \%)$ & $(5.8 \%)$ \\
\hline
\end{tabular}

ground and research interests of the 171 literary critics who responded to the questionnaire were varied. Over $70 \%$ of the participating literary critics were men (124 of 167 respondents) and more than $80 \%$ were tenured (142 of 168 repondents). Seventy-five were professors and 67 were associate professors (see Table 1). The distribution of academic rank corresponded to the distribution of the number of years the respondents had spent researching, writing, and publishing literary criticism. Beginning with their Master's degree work, the number of years the participants had spent doing literary criticism ranged from two to 50 years.

The majority of the degrees held by the participants were granted by North American institutions (see Table 2). Of the respondents who provided data about their degrees, over 90\% held Bachelor's, Master's, and Doctoral degrees; however, there were two who did not have a Bachelor's degree, 12 who did not obtain the Master's degree, and 15 who did not have a doctorate. There were very few critics who had more than three degrees.

Most of the respondents indicated that the areas of literary scholarship in which they work "often" and "very often" were literary criticism (143 of 164 re-

TABLE 3

Areas of Literary Scholarship in Which Literary Critics Work

\begin{tabular}{lccccc}
\hline & \multicolumn{5}{c}{ Frequency } \\
\cline { 2 - 6 } Area of literary scholarship & Rarely & Occasionally & Often & Very Often & N/A \\
\hline Literary criticism & 3 & 16 & 38 & 105 & 2 \\
Literary history & 10 & 36 & 42 & 50 & 5 \\
Literary biography & 39 & 34 & 26 & 17 & 11 \\
Literary bibliography & 32 & 34 & 22 & 18 & 20 \\
Textual editing & 41 & 24 & 21 & 23 & 28 \\
Literary theory & 29 & 37 & 28 & 31 & 12 \\
Philology & 43 & 20 & 8 & 10 & 41 \\
Linguistics & 47 & 22 & 5 & 12 & 42 \\
\hline
\end{tabular}

spondents, 87.2\%) and literary history (92 of 143 respondents, 64.3\%) (see Table 3). The strong interest in literary criticism confirmed that the respondents were appropriate subjects for this study, that is, they are literary critics. The areas in which $50 \%$ or more of the literary critics worked occasionally or more frequently were literary theory, literary biography, literary bibliography, and textual editing. Few literary critics indicated a strong interest in linguistic- related areas as was the case reported by the non-literary critics. Interest in areas of literary study other than the ones listed in the questionnaire were stated by only a few respondents (see Table 4). Six critics reported history and literature- related studies as being areas of additional interest.

Of the 163 respondents who indicated the national literature they studied, approximately one third reported studying more than one type of national literature (see Table 5). This category included the responses which listed more than one national literature as well as the following: continents (e.g., African and European), 
comparative literature, and national literatures which have a language in common (e.g., international literature in English, peninsular Spanish and Latin American, Continental French, and French Canadian). Fourteen national literatures represented the total interests of the respondents. The national literatures were mainly European and North American; the exceptions were Colombian, Chinese, and Jewish.

The languages of the literature that 160 respondents reported studying corresponded to the national literatures they studied (see Table 6). Apart from Hebrew and Chinese the languages reported were modern European. English was

TABLE 4

Other Interests of Literary Critics

\begin{tabular}{|c|c|}
\hline Interest [Specific interests indicated by critics] & Responses \\
\hline $\begin{array}{l}\text { History } \\
\text { [Cultural history, sexual history, history of ideas, historical and cultural } \\
\text { backgrounds to literary works, cultural and intellectual history of } \\
\text { literary scholarship] }\end{array}$ & 6 \\
\hline $\begin{array}{l}\text { Literature-related studies } \\
\text { [Literary styles and devices, medico-literary relations, reception] }\end{array}$ & 6 \\
\hline $\begin{array}{l}\text { Performance and Production studies } \\
\text { [Dramatic theory, performance theory, production history; theater] }\end{array}$ & 5 \\
\hline $\begin{array}{l}\text { Specialized areas of linguistics } \\
\text { [Semantics, phonetics and phonostylistics, neuro- and psycho-linguistics }\end{array}$ & 3 \\
\hline Translation & 3 \\
\hline Aesthetics & 2 \\
\hline $\begin{array}{l}\text { Criticism in other fields } \\
\text { [Music criticism, psychoanalytic criticism] }\end{array}$ & 2 \\
\hline $\begin{array}{l}\text { Other fields } \\
\text { [Medicine, women's studies] }\end{array}$ & 2 \\
\hline Rhetoric & 1 \\
\hline
\end{tabular}

TABLE 5

National Literature Studied by Literary Critics

\begin{tabular}{lr}
\hline \multicolumn{1}{c}{ National Literature } & Responses \\
\hline More than one national literature & 52 \\
American & 6 \\
British & 15 \\
Canadian (excluding French Canadian) & 14 \\
Chinese & 1 \\
Colombian & 1 \\
English & 19 \\
French & 23 \\
French Canadian & 4 \\
German & 10 \\
Irish & 1 \\
Italian & 10 \\
Jewish & 10 \\
Russian & 1 \\
Spanish (Peninsular not Latin American) & 3 \\
\hline
\end{tabular}

indicated by almost half of the subjects. Although approximately one third of the literary critics (52) studied more than one national literature, only $11.9 \%$ (19 of 160 respondents) studied literatures in more than one language. Thus, literary critics who studied more than one national literature tended to adhere to national literatures of the same language, such as English or French. 
The literary periods which 159 of the questionnaire respondents reported studying covered a very broad range, from A.D. 400 to the present (see Table 7). The literary periods which were most frequently cited belonged to this century: 20th century and modern/post-modern/contemporary, respectively. The 162 questionnaire respondents who indicated which literary genres they studied reported varied interests (see Table 8). The most frequently cited category was

TABLE 6

Languages of the Literature Studied by Literary Criticism

\begin{tabular}{lr}
\hline \multicolumn{1}{c}{ Language } & Responses \\
\hline More than one language & 19 \\
Chinese & 1 \\
English (including Canadian, British, American, etc.) & 72 \\
French (including French Canadian) & 33 \\
German & 12 \\
Hebrew & 1 \\
Italian & 10 \\
Russian & 3 \\
Spanish (including Latin American Spanish) & 9 \\
\hline
\end{tabular}

TABLE 7

Literary Periods* Studied by Literary Critics

\begin{tabular}{lc}
\hline \multicolumn{1}{c}{ Literary Period } & Responses \\
\hline More than one literary period & 26 \\
16th Century & 3 \\
17th Century & 5 \\
18th Century & 5 \\
19th Century (including Romantic and Realistic) & 24 \\
20th Century & 47 \\
A.D. 400-1500 Medieval/Middle Ages & 8 \\
1500-1660 Renaissance & 9 \\
1660-1800 Neo-Classical & 5 \\
Modern, post-modern, contemporary & 27 \\
\hline
\end{tabular}

Note: ${ }^{*}$ These categories are modifications of English literary history found in Holman (1980).

the study of more than one genre (38.3\%, or 62 of 162 respondents). The second and third most frequently cited genres were the novel and poetry.

The critical approaches that 155 questionnaire participants reported studying covered a broad range of interests and were represented by 26 categories (see Table 9). Most frequently, literary critics described their critical approach as eclectic. The second and third preferred critical approaches were historical criticism and new criticism. Although questionnaire participants indicated the use of a broad range of critical approaches, the ones most frequently mentioned comprise a small number of approaches, namely, feminist, formalist, historical, new criticism, and eclectic.

\section{THE RESEARCH-PHASES MODEL OF THE LITERARY CRITICAL PROCESS}

The holistic approach used in this study to describe the information-seeking behavior of literary critics links information needs and uses with scholarly activities. However, prior to the present investigation a model of the process of literary criticism was not available, making it necessary to develop one in the first 
TABLE 8

Genres Studied by Literary Critics

\begin{tabular}{lc}
\hline \multicolumn{1}{c}{ Genre } & Responses \\
\hline More than one genre & 62 \\
Drama/Theater & 9 \\
Criticism (exegetical works, literary criticism, novel-criticism) & 2 \\
Fiction & 11 \\
Novel & 38 \\
Poetry (dream visions, epic poetry, verse) & 18 \\
Prose (narrative, letters, journals, prose treatises, psychoanalysis) & 12 \\
No response & 9 \\
\hline
\end{tabular}

TABLE 9

Critical Approaches Used by Literary Critics

\begin{tabular}{lr}
\hline \multicolumn{1}{c}{ Critical approach [Specific approach as indicated by critics] } & Responses \\
\hline Eclectic/Pluralistic & 33 \\
Archetypal & 1 \\
Cultural & 3 \\
Deconstructionist & 4 \\
Feminist & 12 \\
Formalist & 10 \\
Hermeneutic & 1 \\
Historical & 20 \\
Impressionistic & 1 \\
Linguistic Literary & 4 \\
Marxist & 2 \\
New Criticism & 18 \\
New Historicism & 2 \\
Phenomenological & 1 \\
Philosophical & 2 \\
Poststructuralist & 2 \\
Psychoanalytic & 2 \\
Psychological & 2 \\
Reader-response & 2 \\
Rhetorical & 2 \\
Semiotic & 4 \\
Socialist Realistic & 4 \\
Sociological & 2 \\
Structuralist & 7 \\
Difficult to determine & 2 \\
[Analytical, time-space oriented; obsessional networks evident across a writer's & 2
\end{tabular}

phase of the research. The research-phases model of the literary critical process developed from the present study incorporates both scholarly activities and information functions ${ }^{4}$ (see Figures 3 and 4).

The model incorporates six stages: idea generation, preparation, elabora-

\footnotetext{
${ }^{4}$ An expanded model of literary criticism was also developed which details the scholarly activities and information functions of each stage of the literary critical process, and provides information about associated cognitive processes, difficulties experienced in finding information at each stage of the process and other work-related activities (Chu, 1992). For this article all the data are consolidated into two figures that, taken together, represent the research- phases model of literary criticism (see Figures 3 and 4).
} 
FIGURE 3

Research Phases Model of the Literary Critical Process

\begin{tabular}{|c|c|}
\hline $\begin{array}{l}\text { IDEA } \\
\text { STAGE }\end{array}$ & $\begin{array}{l}\text { Generation of idea } \\
\text { Initiation of project } \\
\text { Initial formulation of idea } \\
\text { Decision on literary texts for study } \\
\text { Discussion of idea(s) }\end{array}$ \\
\hline $\begin{array}{l}\text { PREPARATION } \\
\text { STAGE }\end{array}$ & $\begin{array}{l}\text { Searching for primary and secondary materials or resources } \\
\text { Using/reading primary and secondary sources } \\
\text { Taking notes from primary and secondary sources } \\
\text { Trying out idea(s) } \\
\text { Application for funding }\end{array}$ \\
\hline $\begin{array}{l}\text { ELABORATION } \\
\text { STAGE }\end{array}$ & $\begin{array}{l}\text { Thinking of focus for each section of the work } \\
\text { Mapping/sketching idea(s) for work, creation of an outline } \\
\text { Organization of notes to represent structure of work or create } \\
\text { shape of argument } \\
\text { Discussion of idea(s) } \\
\text { Application for funding }\end{array}$ \\
\hline $\begin{array}{l}\text { ANALYSIS \& } \\
\text { WRITING STAGE }\end{array}$ & $\begin{array}{l}\text { Drafting the work } \\
\text { Revision of the work } \\
\text { Obtaining help with work } \\
\text { Searching for more information } \\
\text { Re-reading text(s), notes and other materials } \\
\text { Preliminary exploration of dissemination channels }\end{array}$ \\
\hline $\begin{array}{l}\text { DISSEMINATION } \\
\text { STAGE }\end{array}$ & $\begin{array}{l}\text { Exploration of dissemination channels } \\
\text { Publication or presentation of work } \\
\text { Application for funding }\end{array}$ \\
\hline $\begin{array}{l}\text { FURTHER WRITING } \\
\text { \& DISSEMINATION } \\
\text { STAGE }\end{array}$ & $\begin{array}{l}\text { Exploration of dissemination channels } \\
\text { Searching for more information } \\
\text { Reading and/or re-reading text(s), notes and other materials } \\
\text { Re-writing of work } \\
\text { Publication or presentation of reworked document }\end{array}$ \\
\hline
\end{tabular}

tion, analysis and writing, dissemination, and further writing and dissemination. During the first stage, the literary critic generates and develops an idea. The activities during this stage are mainly solitary, with the exception of literary critics wishing to discuss their idea(s). Information is used minimally and for the pur- 
Legend:

* = Primary functions of information

$>=$ Secondary functions of information

IDEA

STAGE

PREPARATION STAGE

ELABORATION STAGE

ANALYSIS \& WRITING STAGE
* Define or develop one's idea(s)

$>$ Identify which literary text(s) to use

Use of Primary Sources

* To relate the materials to other known information

* To look for support for argument of the study, e.g., quotations, answers, images, themes

* To look for something specific in the text(s) because of the literary critical approach one uses

* To read from a different perspective in the second reading

* To familiarize oneself with the text in the first reading

* To understand the time period when text(s) were published

* To understand the time period covered by work

$>$ To learn more about specific literary critical approaches

$>$ To help in formulating questions

Use of Secondary Sources

* To expand one's knowledge of the subject

* To learn what criticism has been published

* To obtain leads to relevant primary or secondary material

* To ensure that there is no overlap or duplication of own work with published criticism

* To select critical views to include in your work

$>$ To have views reinforced

* To determine what will be central and what will be peripheral to the study

* To focus more precisely on the exact area of interest

Re-reading Text(s), Notes and Other Materials

* To verify a citation

* To see if there are "connections" which may have been missed

* To refamiliarize oneself with the information because time has elapsed between the last reading of materials and start of writing

* To obtain more support for argument of work, e.g., quotations, answers, images, themes

Searching for More Information

* To know about something that is still unclear

* To obtain more support for argument of work, e.g., quotations, answers, images, themes

* To see if there are any new developments 


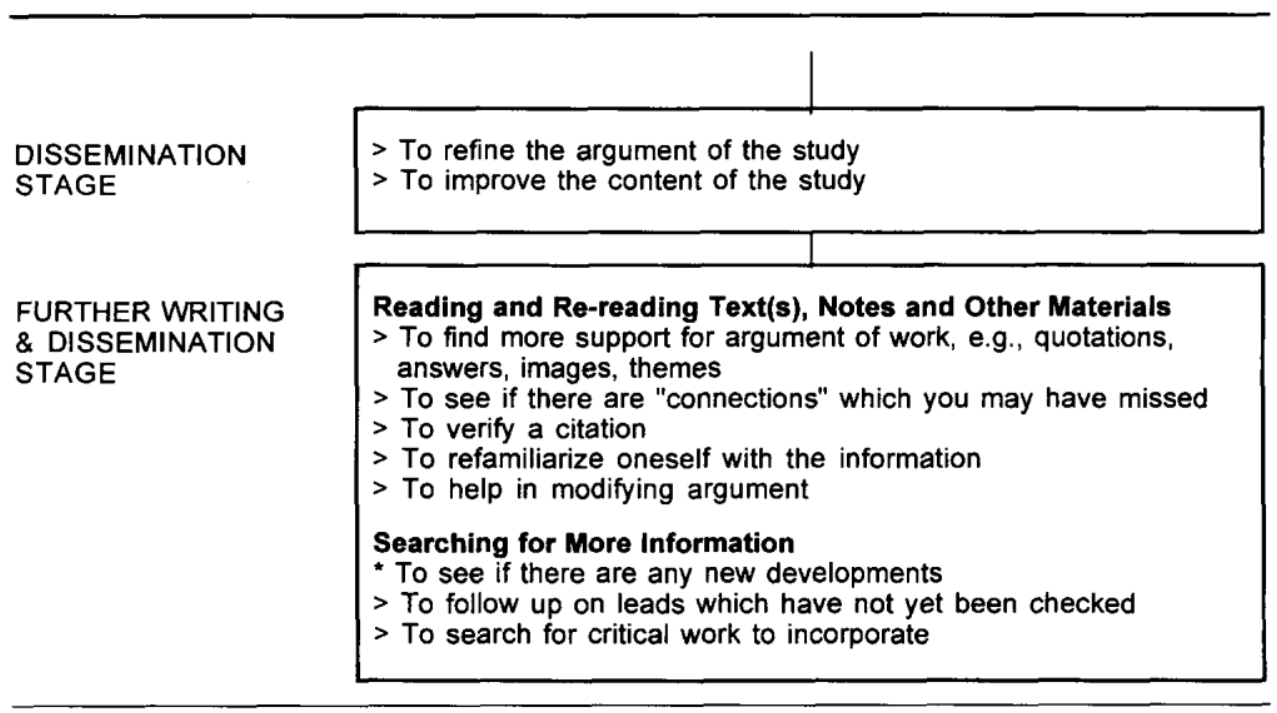

pose of developing ideas and identifying the literary text(s) to be used.

During the preparation stage, the literary critic identifies, locates, and reads the primary and secondary material required to obtain sufficient information to formulate a strategy for writing literary criticism. This stage is marked by substantive use of information, the highest among all the stages. The information needs were for a diverse range of primary and secondary materials. The activities during this stage are also solitary with the possible exception of soliciting help to identify and locate materials needed. The results of this study reveal that the term "research," unlike its use by information professionals and scientists, generally is not used to describe the scholarly process of literary criticism. Instead, the term "research" is specifically associated with information-searching activities, that is, the literature search.

The elaboration stage is mainly a mental process to map the idea(s) for writing, to create an outline, and to organize notes. Other activities pertaining to this stage are the discussion of idea(s) and the application for funding to support scholarly activities. There is minimal use of information for the purpose of focusing the shape of literary criticism.

The analysis and writing stage begins with the solitary activity of writing and usually ends with a request for help with editing and proofreading. This stage is also characterized by extensive use of information with slight to moderate amounts of information searching. Exploration of channels to disseminate literary criticism tends to begin at the analysis and writing stage.

The dissemination stage involves the activities of presenting or publishing a work of criticism. Minimal use of information is required at this stage. Information helps to refine the argument of the criticism or to improve its content. Other activities occurring during this stage are exploration of dissemination channels and application for funding for travel.

The final stage of the model, further writing and dissemination, takes place when applicable. The activities involved in this stage are the reworking and further dissemination of a completed and previously disseminated document. The new document may contain little or no changes and is usually disseminated through a different channel. There is moderate use of information for the purpose of rewriting the document.

These stages of literary criticism, although presented linearly, are not meant to represent a strictly linear and sequential order. The model presents the natural progression of events classified into six stages; however, the transition from one stage to the other is not always clearly delineated. This observation was also noted by a few 
of the interviewees and questionnaire respondents. The "fuzziness" found between stages produces variability in the model. Three factors that influence variations in the model are the number of active projects, the newness of a project (i.e., familiarity with subject), and personal working style. Most of the interviewees worked on several projects and, therefore, were involved at different stages of work in relation to each project. If the subject of a new project is familiar (e.g., an extension of previous work, a different aspect of a previous project), minimal preparation may be required while a new project on an unfamiliar subject will call for stricter adherence to the model. A literary critic may develop a personal style of working based on his or her own personality, mentors' style of work, and/or instruction received in bibliography/library research courses. Depending on which factors may be relevant, a literary critic may have a method of working which is a variation of the six stages. However, irrespective of variations, the process is cyclical, beginning with an idea, ending with a product and starting again (see Figure 5).

There are three primary variations to the model of literary criticism (see Variations la-3a in Figure 6). Each of the variations may be followed by further writing and dissemination, a stage which literary critics may adopt to disseminate the particular work using a different channel. This situation would yield three additional patterns (see Variations $1 b-3 b$ in Figure 6) which expand on the three primary variations.

The first pattern begins with idea generation/elaboration, is followed by analysis and writing, then dissemination, and possibly further writing and dissemination. This variation is marked by the absence of the preparation stage. This situation would be associated with a critic who is working on another aspect or extension of a previous study. Since the subject is familiar, the critic will have extensive knowledge of the subject and will have most of the materials needed. Therefore, there would not be much need for preparation and if information searching is required, it is an activity within the analysis and writing stage.

The second pattern begins with development of an idea, is followed by preparation, then elaboration/analysis and writing, then dissemination, and possibly by further writing and dissemination. This variation is the same as the model 
FIGURE 5

The Cyclical Process of Literary Criticism

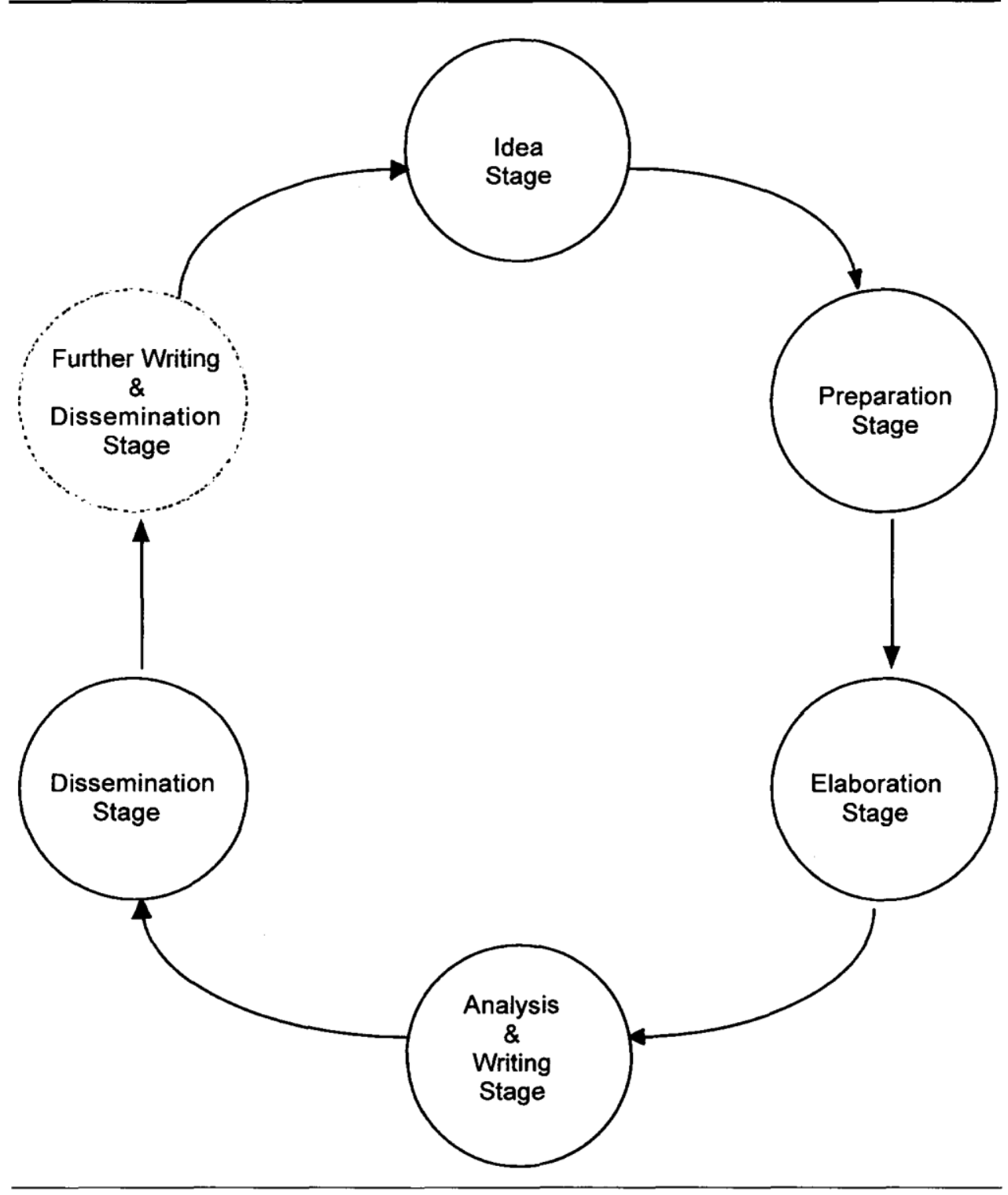

except that the elaboration stage is not distinguished from the analysis and writing process. Once a critic is prepared to write, writing and elaboration take place concurrently.

The third pattern begins with idea development, is followed by preparation/ analysis and writing, then dissemination, and possibly further writing and dissemination. This variation is characterized by the absence of the elaboration 
FIGURE 6

Variations to the Model of Literary Criticism

\begin{tabular}{|c|c|c|}
\hline Variation 1a & Variation 2a & Variation 3a \\
\hline Idea Generation/Elaboration & Idea Generation & Idea Generation \\
\hline Analysis and Writing & Preparation & $\begin{array}{l}\text { Preparation/Analysis and } \\
\text { Writing }\end{array}$ \\
\hline \multirow[t]{2}{*}{ Dissemination } & $\begin{array}{l}\text { Elaboration/Analysis and } \\
\text { Writing }\end{array}$ & Dissemination \\
\hline & Dissemination & \\
\hline Variation 1b & Variation 2b & Variation 3b \\
\hline Idea Generation/Elaboration & Idea Generation & Idea Generation \\
\hline Analysis and Writing & Preparation & $\begin{array}{l}\text { Preparation/Analysis and } \\
\text { Writing }\end{array}$ \\
\hline Dissemination & $\begin{array}{l}\text { Elaboration/Analysis and } \\
\text { Writing }\end{array}$ & Dissemination \\
\hline \multirow[t]{2}{*}{$\begin{array}{l}\text { Further Writing and } \\
\text { Dissemination }\end{array}$} & Dissemination & $\begin{array}{l}\text { Further Writing and } \\
\text { Dissemination }\end{array}$ \\
\hline & $\begin{array}{l}\text { Further Writing and } \\
\text { Dissemination }\end{array}$ & \\
\hline
\end{tabular}

stage. In this situation, a critic would begin writing soon after reading only some materials. Such critics like to write down the thoughts they gather as they read (i.e., alternating between reading and writing) and, in such a manner, slowly build up, through many re-writes, to a complete draft.

It is difficult to ascertain how many critics adhere to the model or one of its variations, or when a certain pattern may be more applicable to a specific type of study. In any case, the recognition of the variations to the model does not detract from its value as all of the variations incorporate all stages of the model in a different manner of progression. Other studies of the research process in the humanities, although with fewer observations, have resulted in similar findings. For example, Uva's (1977) study of the research phases in historical research revealed that "often there is overlapping between stages with work going on in several stages simultaneously" (p. 16) and Stone's (1980) study of eight humanities scholars identified five research steps that could proceed in sequence as well as in parallel. Similarly, an Investigation into Information Requirements of the Social Sciences (INFROSS) carried out between 1968 and 1971, which asked respondents to record stages of their research in chronological order, found that research stages "do indeed occur, but not as stages; they overlap and intermingle" (Line, 1973, p. 18). For example, "some data collection may take place before a hypothesis is formulated, preliminary analyses may necessitate the collection of more or different data and the use of a different methodology - and part of a report may be written well before the work has been completed" (Line, 1973, p. 18). Thus, three conceptual models were developed from the INFROSS study that include a linear model, a cyclic model (described later in this article), and a generalized model which presents the complex links between the elements (Line, 1974).

The time spent to produce a work of literary criticism is difficult to determine because literary criticism normally is not a continuous and isolated process, the materials needed may not be readily available, the length and difficulty of the criticism varies, and the critics may be working on concurrent projects. Therefore, a reliable measure of the time spent producing a work of literary criticism is the proportion of time spent working on each stage, beginning at the idea stage and ending with the dissemination stage. The respondents reported spending most of their time on the analysis and writing, and preparation stages. 


\section{CONTEXTUALIZING THE WORK OF LITERARY CRITICS}

In order to understand the conditions in which literary critics work, data were obtained to understand their perceptions of their work, assistance they received to advance their work, formal and informal channels of information, type of literary critical approach used, source of their ideas, bibliographic instruction received, difficulties experienced producing literary criticism, and preferred forms of dissemination. The participants provided a positive view of their work in their responses, suggesting that literary criticism is an intellectual, creative, enjoyable, and for the most part, solitary process. There was a strong sense that they valued their work.

The respondents reported needing very little help with their work. The types of help reported include: intellectual, emotional, informational, editorial, and technical. Intellectual help was obtained through exchanges with colleagues or with students who provided stimulus and intellectual feedback. Encouragement and emotional support, provided by family and friends, is an important motivation factor. Informational help involved the need for bibliographic or factual information or materials. Informational help was obtained from libraries, colleagues, conferences, students, and the materials themselves. Editorial help, including proofreading, was needed at the analysis and writing or dissemination stages. This type of help was provided by family and colleagues. Technical help included typing and computer help, which were obtained from colleagues, research assistants, family, and secretaries. The places the interviewees primarily relied on for materials are academic libraries and personal collections.

Both formal and informal channels of information are important sources for obtaining information. This finding supports some recent research suggesting the relative importance of informal channels of communication in the humanities (Lönnqvist, 1990, p. 29; Pandit, 1992) although earlier studies suggested that informal communication had relatively little importance (e.g., Hopkins, 1988). In addition to family, friends, colleagues, and students other important informal sources are conferences and colloquia. Attendance at both types of events may take place because the subject is of interest. Other reasons reported for attending conferences included listening to other research, and for attending colloquia included supporting a colleague and the department. The types of help received at conferences were networking and sense of community, while colloquia provided a forum for new ideas and feedback.

The literary critical approaches used by the participants were diverse. The use of an eclectic approach to literary criticism was most frequently reported. The participants reported that the literary critical approach they used affected their work. Most frequently, the critical approach they used dictated the amount and type of information required, provided a methodology to guide analysis, promoted self-reliance and originality, and emphasized close textual analysis.

The ideas for literary criticism most often originate from issues arising from previous work or from teaching. This finding suggests that for many critics, a new project builds on an established knowledge base and information resources. Such a situation indicates that literary critics do minimal searching for information in the generation of new ideas.

The majority of the literary critics (20 of 31 respondents) interviewed in the first phase of the study had some form of bibliographic instruction. Formal bibliographic training had been obtained through a course (17), tour (9), or class instruction/workshop (3). Alternative types of training included self-taught methods (5), individual instruction from librarians (4), information on pathfinders (1), and computer-assisted instruction (1). The large number of literary critics who had obtained bibliographic instruction is an indicator of the familiarity they have with a library's information systems and collection.

The literary critics reported few difficulties in conducting research for literary criticism and in finding information. Problems were most frequently encountered during the idea and preparation stages, with the fewest reported in the further writing and dissemination stage. The difficulties found consistently across all stages concerned access to materials and the lack of resources. 
The preferred forms of dissemination are journal articles, conference presentations, books, and colloquia. The reasons reported for disseminating literary criticism include personal benefit (e.g., professional advancement, exposure) and professional benefit (e.g., to enrich the discipline and share the work).

\section{COMPARISON WITH OTHER MODELS OF RESEARCH PHASES}

Research-phase studies are important in identifying the stages of research and the information functions within that process. The identification of these phases is important in order to understand information-seeking behavior. The phase identification approach was used in this study to develop a model from which to begin to understand the information needs and uses of literary critics, thereby enabling comparisons between literary scholars and scholars from other disciplines.

Findings from research-phase studies of other disciplines are compared here with those found in the present study. It is difficult to conduct a comparative study of the models because the unit used to describe/represent a stage, phase, or step in the process of research or scholarship varies in scope. Nevertheless, it is important to note points of similarity and difference. The number of research phases reported in the sciences and social sciences (see Figure 7) range considerably, for example, economists may have as few as three phases (White, 1975), while scientists may go through as many as eleven (Garvey, Tomita, \& Woolf, 1979). In the INFROSS study of social scientists, three models of the research procedure in the social sciences were developed: the linear, generalized, and cyclic models (Line, 1974). The linear and generalized models include five stages that incorporate micro elements associated with each stage. The cyclic model includes six stages (see Figure 7). Unlike the concise model of economists which only describes methodology as one phase, the model for social scientists

FIGURE 7

Research Phases of Scientists and Social Scientists

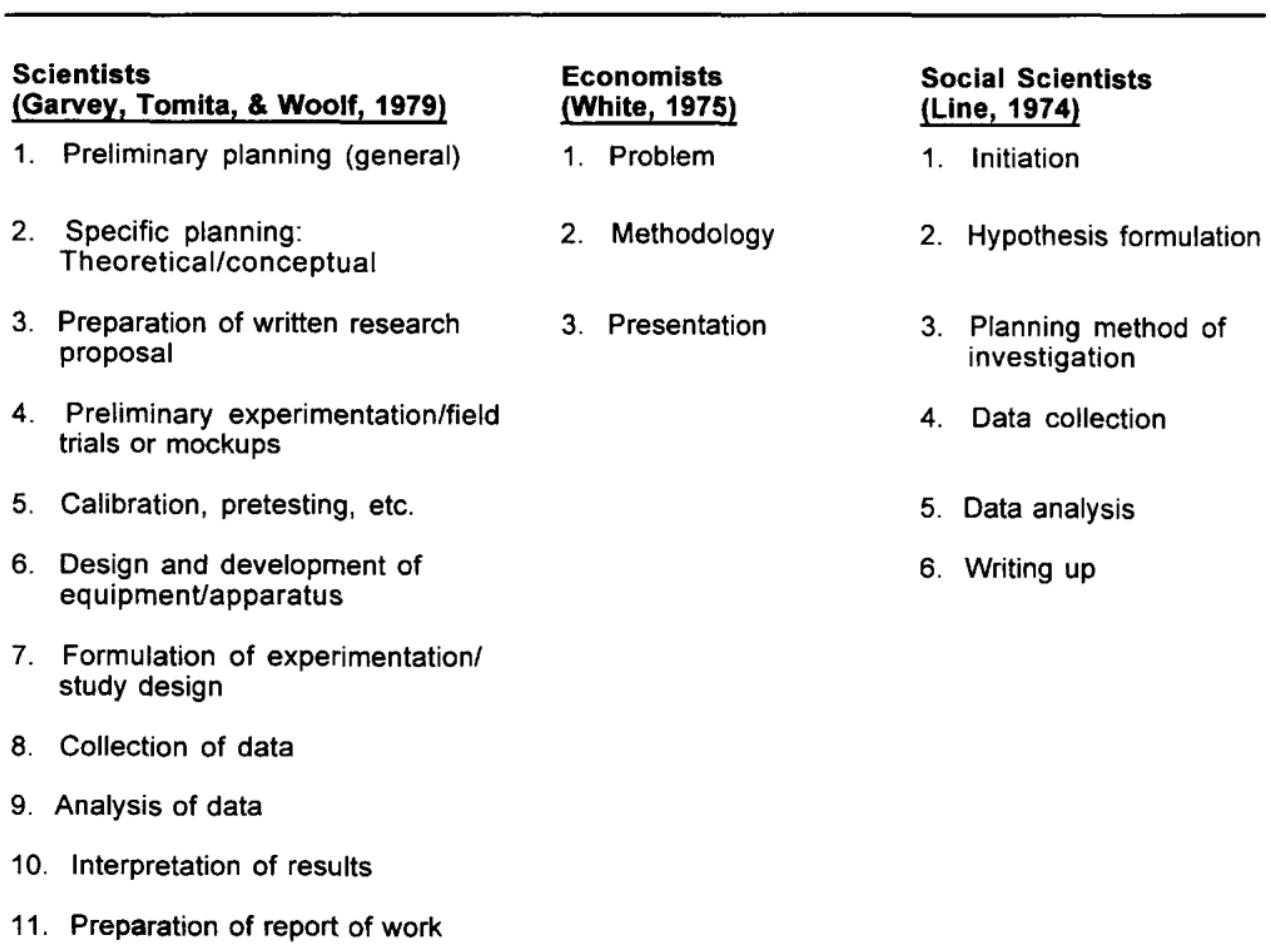

represents it in three phases: planning method of investigation, data collection, and data analysis.

Two models of research phases in the humanities were identified (see Figure 8). Stone (1980) described the research process of humanities scholars in terms of five actions and Uva's study (1977) of academic historians reports a five- stage process. My six-stage model of literary critics is offered for contrast. From initial observation, a difference that is readily detected relates to analysis as an activity during research. In Stone's 
model this activity is absent; in the Uva model it occurs prior to writing; and in my model it is linked to the writing process. In the experience of literary critics, and probably in the work of other humanists, analysis cannot be disconnected from the writing process.

All of the frameworks presented suggest a common start to the research process beginning with the selection of a problem or the initial planning of research. This initial stage corresponds with the model of literary criticism developed in the present study. Similarly, all the models have a common end phase, that is, the generation of written documents. In the present study, this end phase is referred to as the dissemination of one's work. This terminology, unlike that used in the other models, suggests that scholarly communication is cyclical and that research involves not just the generation of information but its communication. Unique to the literary critics' model is the identification of further writing and dissemination, a stage which, however, is not unique to literary critics. The practice of this activity has been observed in the sciences, social sciences, and other disciplines in the humanities. For example, it is not uncommon for a scholar to present a paper at a conference, followed by its submission for journal publication.

Aside from the similarities found in the initial and final stages, the remaining

FIGURE 8

Research Phases of Humanists

\begin{tabular}{|c|c|c|}
\hline $\begin{array}{l}\text { Humanities Scholars } \\
\text { (Stone, 1980) }\end{array}$ & $\begin{array}{l}\text { Academic Historians } \\
\text { (Uva, 1977) }\end{array}$ & $\begin{array}{l}\text { Literary Critics } \\
\text { (Chu, 1992) }\end{array}$ \\
\hline 1. Thinking and talking to people & 1. Problem selection & 1. Idea Generation \\
\hline $\begin{array}{l}\text { 2. Reading what has already been } \\
\text { done in the field }\end{array}$ & $\begin{array}{l}\text { 2. Detailed planning } \\
\text { of data collection }\end{array}$ & 2. Preparation \\
\hline $\begin{array}{l}\text { 3. Studying original sources and } \\
\text { making notes }\end{array}$ & 3. Data collection & 3. Elaboration \\
\hline 4. Drafting the write-up & $\begin{array}{l}\text { 4. Analysis and } \\
\text { interpretation }\end{array}$ & 4. Analysis and writing \\
\hline 5. Revising the final draft & 5. Writing-rewriting & $\begin{array}{l}\text { 5. Dissemination } \\
\text { 6. Further writing and } \\
\text { dissemination }\end{array}$ \\
\hline
\end{tabular}

stages differ among the various models presented. The models for scientists, economists, social scientists, and academic historians include steps that are associated with a "scientific" approach, such as planning the methodology, writing a research proposal, applying for funding, and data collection, analysis, and interpretation. The economists' model also encompasses all of these activities but uses only one term to represent them: methodology.

The humanists' model (Stone, 1980) is reported in terms of courses of action. The steps are comparable to those comprising the literary critics' model. The two steps in Stone's model: reading what has already been done in the discipline, and studying original sources and making notes, are typical of the activities in the preparation phase of literary criticism. The analysis and writing stage in literary criticism incorporates two of the steps in Stone's research phases for humanists: drafting the write-up and revising the final draft. However, as noted earlier Stone's model does not explicitly incorporate analysis as a research activity.

The comparison of research-phase models of various disciplines suggests that the strongest parallel with the literary critical model is Stone's model for humanities scholars. For instance, Stone's five steps, translated into the terminology of the literary critics' model, correspond to the following stages: idea, preparation, and analysis and writing. This parallel shows that literary critics, a subset of humanists, do follow a scholarly process similar to humanists as a whole. 


\section{CONTRIBUTIONS OF THE STUDY}

\section{Implications for Research Methodology}

Previous studies have tended to start with a model taken from the sciences (or in later studies, the social sciences), then used this model as a template against which to compare the humanities scholars who are, then, in some respects, seen as falling short if their work does not fit all of the categories of scientific work. The use of an ethnographic approach in which the respondents describe in their own terms and from their own perspective how they view their work is an important departure from this tradition. In the present study, the use of various methods to gather the data for model building and testing suggests that triangulation ${ }^{5}$ is effective for yielding valid and reliable data. Research phases, a holistic approach to studying information-seeking behavior, enabled a fuller understanding of the complexity of the literary critical process. For instance, it revealed that literary criticism is not a clearly defined step-by-step sequential process, the way most scientific and social scientific work appears to be.

\section{Implications for Future Research}

Information professionals require an understanding of their users in order to be responsive to their needs. They have looked to information needs and uses studies for such knowledge. In the past, these studies have focused generally on material and institutional use. However, such data give only a partial idea of information needs and uses. In contrast, the results of the present study offer information workers a deeper understanding of the research activities conducted by literary critics: specifically, the context from which information needs germinate, the specific functions of information channels in literary critical work, and the nature of the information needs that arise in each stage of research. It is recognized that information needs and uses studies of the humanities as a whole are important and needed. However, discipline-specific knowledge, such as that provided in this study, is also critical for research institutions, libraries, and archives that focus on serving the pressing needs of particular scholars.

Research beyond exploratory studies is needed. Much of the information needs and uses studies in the humanities are exploratory in nature and have tended to use few observations to begin making generalizations. Such findings require further investigation to test their reliability as well as external validity. The use of research phases, as a holistic approach, and triangulation offer a valid methodology for tackling informationseeking behavior research.

Although much has been learned about the work of literary critics and their information needs and uses, there is yet more to be discovered about these scholars, their work, and their scholarly communication process.

Examples include a study of the:

- Context within which ideas originate;

- Motivational factors in conducting literary criticism. For example, the extent that "love" of one's work motivates a scholar and whether this "love" persists throughout one's career;

- Nature of the work in collaborative projects;

- Informal channels of communication by literary scholars, to build on prior research that have studied humanities scholars in general; and

- Way information technologies and the availability of electronic texts may be affecting literary critics' work, communication, and information-seeking behavior.

\section{CONCLUSION}

\footnotetext{
${ }^{5}$ Triangulation is the use of two or more methods to collect data to study a research problem. By bringing two or more independent measurement processes to bear on a problem, triangulation reduces uncertainty in data interpretation; thereby, increasing research validity (Webb et al., 1981).
} 
This research has provided insight into the information-seeking behavior of literary critics, a group which has not received exclusive or in-depth attention in information-seeking studies. In particular their informationseeking behavior was studied in the context of the production of literary criticism, a process which is represented by a set of research and information activities. Information was considered as an element not only used by literary critics but one that advances their research activities. These research activities were translated into research phases which allowed for comparative study of the research phases in other disciplines. The most similarity was found with a research-phases model for humanists (Stone, 1980). In summary, this study found that literary critics have a positive view of their work; they needed very little assistance from others; they used both formal and informal channels of information; they used a diversity of literary critical approaches; their ideas originated most often from their earlier work or their teaching; most have had bibliographic instruction; few difficulties were experienced while conducting their work or finding information; and the two most preferred forms of dissemination were journal articles and conference papers. Finally, this article points the direction to further research that can attempt to explain the different aspects of literary critics' informationseeking behavior.

\section{REFERENCES}

Abrams, M.H. (1997). The transformation of English studies: 1930-1995. Daedalus, 126, 105-131.

Barry, Christine A. (1997). The research activity timeline: A qualitative tool for information research. Library \& Information Science Research, 19, 153-179.

Batts, Michael S. (1972). Citations in the humanities: A study of citation patterns in literary criticism in English, French and German. IPLO Quarterly, 14, 20-40.

Beh, Yolanda. (1983). Library and information resources and services for users in language and literature. In Congress of East Asian Librarians, The library in the information revolution (6th ed). (pp. 500-529). Singapore: Maruzan Asia. Beugnot, Bernard. (1981). La notion de document et la recherche littéraire

[Documentation and literary research]. Argus, 10, 19-20.

Brown, Jennifer, \& Sime, Jonathan. (1981). A methodology for accounts. In M. Brenner (Ed.), Social method and social life (pp. 159-188). London: Academic.

Budd, John. (1986a). Characteristics of written scholarship in American litera-

ture: A citation study. Library \& Information Science Research, 8, 189-211. Budd, John. (1986b). A citation study of American literature: Implications for collection management. Collection Management, 8(2), 49-62.

Budd, John. (1990). Citation characteristics of Italian and Spanish literary monographs. Library Quarterly, 60, 337-356.

Chu, Clara M. (1992). The scholarly process and the nature of the information needs of the literary critic: A descriptive model. Unpublished doctoral dissertation, University of Western Ontario.

Cullars, John. (1985). Characteristics of the monographic literature of British

and American literary studies. College \& Research Libraries, 46, 511-522.

Cullars, John. (1988). Characteristics of the monographic scholarship of foreign literary studies by native speakers of English. College \& Research Libraries, 49, 157-170.

Cullars, John. (1989). Citation characteristics of French and German literary monographs. Library Quarterly, 59, 305-325.

Dervin, Brenda, \& Clark, Kathleen. (1987). ASQ: Alternative tools for information need and accountability assessments by libraries. Belmont, CA: The

Peninsula Library System.

Dervin, Brenda, \& Nilan, Michael. (1986). Information needs and uses. In M. Williams (Ed.), Annual review of information science and technology (pp. 3-33). White Plains, NY: Knowledge Industry Publications.

Doland, Virginia. (1984). Portrait of the critic as journal reader: A study of readership patterns among literary scholars. In B. Flood, J. Witiak, \& T.H. Hogan (Comps.), Challenges to an information society (pp. 222-226). White Plains, NY: Knowledge Industry Publications.

Frost, Carolyn 0. (1979). The use of citations in literary research: A prelimi-

nary classification of citation functions. Library Quarterly, 49, 399-414. 
Garvey, William D., Tomita, Kazuo, \& Woolf, Patricia. (1979). Appendix H: The dynamic scientificinformation user. In W.D. Garvey (Ed.), Communication: The essence of science (pp. 256-279). New York: Pergamon.

Gleaves, Edwin S., Jr. (1961). Characteristics of the research materials used by scholars who write in journals in the field of American literature. Unpub-

lished master's dissertation, Emory University, 1960. (ACRL Microcard, 130). Heinzkill, Richard. (1980). Characteristics of references in selected scholarly English literary journals. Library Quarterly, 50, 352-365. Holman, C. Hugh. (1980). A handbook to literature (4th ed). Indianapolis: Bobbs-Merrill Educational Publishers.

Hopkins, Richard L. (1988). The information seeking behaviour of literary scholars in Canadian universities. Unpublished doctoral dissertation, University of Toronto.

Information problems in the humanities. (1975). A report on the British Library seminar (Report No. 5259).

West Yorkshire: British Library.

Jaaskalainen, Taina. (1985). Viitteiden funktiosta humanistisissa ja muissa tieteissa [Citation functions in humanities and other fields]. Kirjastotiede ja Informatiikka, 4(3), 63-68.

Line, Maurice B. (1973). Information and the research process. SSRC Newsletter 20, 18-19.

Line, Maurice B. (1974). Information requirements of the social sciences. Ac-

cess to the literature of the social sciences and humanities: Proceedings of the conference on access to knowledge and information in the social sciences and

humanities (pp. 146-158). Flushing, NY: Queens College Press.

Lipking, Lawrence. (1981). Literary criticism. In J. Gibaldi (Ed.), Introduction

to Scholarship in Modern Languages and Literatures (pp. 79-97). New York: The Modern Languages

Association of America.

Lönnqvist, Harriet. (1990). Scholars seek information: Information-seeking behaviour and information needs of humanities scholars. Papers presented at the International Federation of Library Associations (IFLA) 56th

General Conference, Joint Workshop Papers, Booklet 7, p. 29. (ERIC Document Reproduction Service No. ED 329 288).

Menzel, Herbert. (1966). Information needs and uses in science and technology. In C. Cuadra (Ed.), Annual review of information science and technology (pp. 41-69). New York: Interscience Publishers.

Menzel, Herbert. (1967). Can science information needs be ascertained empirically? In L. Thayer (Ed.), Communication: Concepts and perspectives (pp. 279-295). Washington, DC: Spartan Books.

Pandit, Idrisa. (1992). Informal communication in the humanities: A qualitative inquiry. Unpublished doctoral dissertation, University of Illinois at Urbana-Champaign.

Stern, Madeleine. (1983). Characteristics of the literature of literary scholarship. College \& Research Libraries, 44, 199-209.

Stone, Sue. (1980). CRUS humanities research programme. In S. Stone (Ed.),

Humanities information research: Proceedings of a seminar; Sheffield 1980

(BLR\&DD Report No. 5588, pp. 15-26). Sheffield, England: Centre for Research on User Studies, University of Sheffield.

Uva, Peter A. (1977). Information-gathering habits of academic historians: Report of the pilot study. Syracuse, NY: SUNY Upstate Medical Center. (ERIC Document Reproduction Service No. ED 142 483).

Watson-Boone, Rebecca. (1994). The information needs and habits of humanities scholars. $R Q, 34,203-216$.

Webb, Eugene T. et al. (1981). Nonreactive measures in the social sciences (2nd ed). Boston: Houghton Mifflin.

White, Marilyn Domas. (1975). The communications behavior of academic economists in research phases. Library Quarterly, 45, 337-354. 